\title{
PENGEMBANGANMEDIAPEMBELAJARAN BERBASIS \\ MACROMEDIA FLASH 8 DENGAN PEDEKATAN \\ CONTEXTUAL TEACHING AND LEARNING \\ PADA MATERI BANGUN RUANG \\ KELAS V SD
}

\author{
Rieke Alyusfitri ${ }^{1}$, Ambiyar ${ }^{2}$, Ishak Aziz ${ }^{3}$, Dia Amdia ${ }^{4}$ \\ 1,2,3Program Doktor Ilmu Pendidikan Pasca Sarjana, Universitas Negeri Padang \\ ${ }^{4}$ Pendidikan Guru Sekolah Dasar, Universitas Bung Hatta \\ alyusfitririeke@gmail.com
}

\begin{abstract}
Lack of student interest in learning. This is because in presenting the material the teacher still uses textbooks provided by the school, so it is necessary to develop a mathematics learning media based on macrmedia flash 8 . This study aims to develop mathematics learning media based on macromedia flash 8 with a Contextual Teaching and Learning approach. The material on the material of Building Classroom V SDN 55 Padang. This research is a development research. This research was conducted in the even semester of 2019/2020 with the research subjects of the VB class students of SD N 55 Aia Pacah Padang. The results showed that the average value of validity was $96.3 \%$. With very valid criteria, the average value of practicality was $94.1 \%$. With very practical criteria. From these data, it is concluded that the development of interactive learning media for the building space is very valid, and very practical in learning mathematics in class V elementary school.
\end{abstract}

Keywords: Development, Learning Media, Macromedia Flash 8, Contextual Teaching and Learning

\begin{abstract}
Abstrak
Kurang tertariknya siswa dalam pembelajaran. Hal ini disebabkan karena dalam penyajian materi guru masih menggunakan buku paket yang disediakan oleh sekolah, sehingga perlu dikembangkan suatu media pembelajaran matematikayang berbasis macrmedia flash 8. Penelitian ini bertujuan untuk mengembangkan media pembelajaran matematika berbasis macromedia flash 8 dengan pendekatan Contextual Teaching andLearningMateri pada materi Bangun Ruang Kelas V SDN 55 Padang. Penelitian ini adalah penelitian pengembangan. Penelitian ini dilakukan pada semester genap 2019/2020 dengan subjek penelitian siswa kelas VB SD N 55 Aia Pacah Padang. Hasil penelitianmenunjukannilairata-ratavaliditas 96,3\% dengan kriteria sangat valid, nilai rata-rata praktikalitas $94,1 \%$ dengan kriteria sangat praktis. Dari data tersebut disimpulkan bahwa pengembangan media pembelajaran interaktif bangun ruang tersebut sangat valid, dan sangat praktis dalam pembelajaran matematika dikelas V sekolah dasar.
\end{abstract}

Kata kunci: Pengembangan Media, Macromedia Flash 8, Contextual Teaching and Learning

\section{PENDAHULUAN}

Menurut (Saputra \& Permata, 2018) Geometri merupakan suatu hal yang sangat berhubungan dalam pendesainan, karena ruang lingkup geometri adalah mengenai garis dan sudut, bangun datar, bangun ruang, kesimetrian, kesebangunan, kekongruenan, dan geometri analitis. Dalam mempelajari geometri siswa membutuhkan konsep yang matang sehingga siswa mampu menerapkan ketrampilan geometri yang dimiliki seperti memvisualisasikan, mengenal bermacam - macam bangun datar dan ruang, mendeskripsikan gambar (Rahayu \& Hidayati, 2018) 
Bangun ruang merupakan bangun tiga dimensi yang memiliki ketinggian dan ketebalan.Bangun ruang dibentuk oleh daerah segi banyak yang disebut dengan sisi, dan biasanya bagian datar dari suatu bangun ruang disebut dengan permukaan.Bangun ruang terdiri dari balok, kubus, kerucut, pisma, limas, tabung. Sifat-sifat dari setiap bangun ruang terdiri atas sisi, rusuk, dan titik sudut. Sisi merupakan bidang yang membatsi suatu bangun ruang. Rusuk adalah garis yang merupakan pertemuan atau perpotongan sisi-sisi pada suatu bangun ruang, sedangkan titik susdut merupakan titik potong dari beberpa rusuk, (Sipayung, 2018).

Materi Bangun Ruang merupakan salah satu materi yang diajarkan pada tingkat Sekolah Dasar (SD) khusunya pada kelas V SD. Siswa menganggap matematika sebagain pelajaran yang sulit, salah satu nya adalah materi bangun datar yang dikarenakan siswa kurang mampu membayangkan konsep volume bangun ruang karena hanya disajikan dalam bentuk dua dimensi pada buku pelajaran. Perkembangan teknologi yang canggih ini dapat menjadikan solusi untuk mengatasi permasalahan dalam pembelajara matematika termasuk dalam hal ini materi bangun ruang yang memerlukan media untuk mempermudah dan memvisualisasikan objek yang bersifat abstrakdalam proses pembelajaran. Dengan memanfaatkan media pembelajaran berbasis teknologi informasi maka akan membatu guru dalam proses pembelajaran. Salah satu cara penggunaan teknologi dalam pembelajaran yaitu pemanfaatan sumber daya teknologi sebagai media dalam proses pembelajaran (Akhmadan, 2017)Proses pendidikan tidak dapat dipisahkan dari proses pembelajaran (Masykur et al., 2017). Berkembangnya ilmu pengetahuan dan teknologi berpengaruh dan membawa perubahan pada dunia pendidikan.

Perkembangan teknologi dapat dijadikan sebagai solusi untuk membuat media pembelajaran agar lebih menarik minat belajar siswa dan membantu siswa dalam memvisualisasikan konsep matematika yang bersifat abstrak serta mempermudah guru dalam menyampaikan materi pembelajaran. (Sutopo, 2011) menyatakan bahwa siswa akan lebih memahami konsep apabila materi yang di ajarkan dipadukan dengan grafis, animasi dan video. Menurut (Fahmi \& Email, 2014), sajian audio visual atau lebih dikenal dengan multimedia dapat dimanfaatkan untuk mengkonkritkan sesuatu yang abstrak. Stimulus visual membuahkan hasil belajar yang lebih baik untuk tugas-tugas seperti mengingat, mengenali, mengingat kembali, dan menghubungkan fakta dan konsep. Sedangkan, stimulus verbal memberi hasil belajar yang lebih apabila pembelajaran itu melibatkan ingatan yang berurut-urutan (sekuensial). Oleh karena itu, agar siswa dapat membayangkan bentuk tiga dimensi dari bangun ruang maka diperlukan suatu media pembelajaran, salah satunya adalah macromedia flash 8 .

Menurut (Sutriyono et al., 2020) Macromedia Flash merupakan sebuah program animasi yang telah banyak digunakan oleh para animator unttuk menghasikan animasi tiga dimensi yang professional. Senada dengan (Setyono et al., 2017)menyatakan bahwa Macromedia Flash 8 merupakan software yang berisi fasilitas untuk membuat desain dan media interaktif yang dilakukan 
secara professional serta hal-hal yang berkaitan dengan sarana yang dibutuhkan untuk menyusun konten pada multimedia. Animasi Interaktif merupakan suatu proses dalam menyampaikan sesuatu dengan menyampaikannya dalam bentuk video, atau gambar bergerak yang dikendalikan oleh Komputer kepada penonton dan juga ada audio yang dapat didengar serta efek grafiknya yang ditimbulkan dapat menarik penonton (Syafwan et al., 2017). (Sakti et al., 2012)menyatakan bahwa pembelajaran melalui media berbasis Macromedia flash dapat menumbuhkan minat belajar dan pemahaman konsep.

Salah satu kontribusi media pembelajaran berbasis macromedia flsh 8 pada pembelajaran adalah membuat pembelajaran lebih interaktif dengan menerapkan metode pembelajaran. Salah satu metode pembejaran yang cocok digunakan dengan macromedia flash adalah pendekatan Contextual Teaching and Learning.

Pembelajaran kontekstual adalah integrasi pengetahuan ke dalam aplikasi kehidupan nyata. Hal ini merupakan kerangka kerja yakni siswa difasilitasi dalam menghubungkan yang dipelajari dengan dunia nyata. Pembelajaran kontekstual adalah filosofi pendidikan yang percaya bahwa pembelajaran dapat ditingkatkan dengan menghubungkan materi ke dalam konteks kehidupan dan pekerjaan yang mungkin diketahui siswa (Trisnawati, 2015). Dengan pembelajaran ini memungkinkan pembelajaran menjadi lebih menyenangkan Karena pembelajarannya dilakukan secara alamiah sehingga siswa dapat melakukan secara langsung dengan hal-hal yang dipelajarinya.

Contextual Teaching and Learning (CTL) merupakan konsep belajar yang membantu guru mengaitkan antara materi yang diajarkannya dengan situasi dunia nyata siswa dan mendorong siswa membuat hubungan antara pengetahuan yang dimiliknya dengan penerapannya dalam kehidupan mereka sebagai anggota keluarga dan masyrakat. (Depdiknas dalam (Subaidi, 2016)). Dengan mengaitkan isi materi pembelajaran dan pengalaman dalam proses pembelajaran, siswa akan lebih mudah menemukan makna, dengan kata lain dengan makna inilah yang akan memberikan alasan siswa untuk belajar dengan baik. Semakin banyak isi materi pembelajaran yang mampu siswa kaitkan dengan lingkungan maka semakin banyak pula makna yang akan didapat dari pembelajaran. Sehingga pembelajaran dengan pendekatan Contextual Teaching and Learning (CTL) diharapkan mampu memberikan hasil pembelajaran yang lebih bermakna bagi siswa. (Sulistyowati, 2013). Senada dengan (Azriah, 2018)menyatakan bahwa Contextual Teaching and Learning (CTL) merupakan suatu konsepsi yang membantu guru menghubungkan konten materi ajar dengan situasi-situasi dunia nyata dan memotivasi siswa untuk membuat hubungan antara pengetahuannya dan penerapannya ke dalam kehidupan mereka sebagai anggota keluarga, warga negara, dan tenaga kerja. Dengan kata lain, CTL adalah pembelajaran yang terjadi dalam hubungan erat dengan pengalaman sebenarnya

Objek-objek bangun ruang banyak ditemukan dalam kehidupan sehari-hari. Ini berarti konsep-konsep yang ada pada bangun ruang harus benar-benar dikuasai dan dipahami oleh siswa. Pemahaman konsep bangun ruang melaui pendekatan Contextual Teaching and Learing memberi kesempatan siswa untuk menemukan kembali konsep dengan pendekatan CTL yang dirancang oleh 
guru yang disajikan dalam bentuk tiga dimensi menggunakaan media pembelajaran macromedia flash.Penelitian ini bertujuan untuk mengembangan media pembelajaran yang valid dan praktis.

\section{METODE}

Penelitian yang dilakukan ini adalah jenis penelitian pengembangan atau dalam bahasa Inggris disebut Research and Development (R\&D), Sugiyono dalam (Batul, 2018). mendefinisikan metode penelitian $\mathrm{R} \& \mathrm{D}$ adalah metode penelitian yang digunakan untuk menghasilkan produk tertentu dan menguji keefektifan produk tersebut. Model pengembangan penelitian yang digunakan dalam penelitian ini adalah model pengembangan 4-D (Define, Design, Develop dan Disseminate).Namun penelitian ini hanya sampai pada tahap pengembangan saja, sedangkan tahap penyebaran tidak dilakukan karena keterbatasan waktu.Penelitian hanya sampai pada tahap 3-D (Define, Design, Develop).

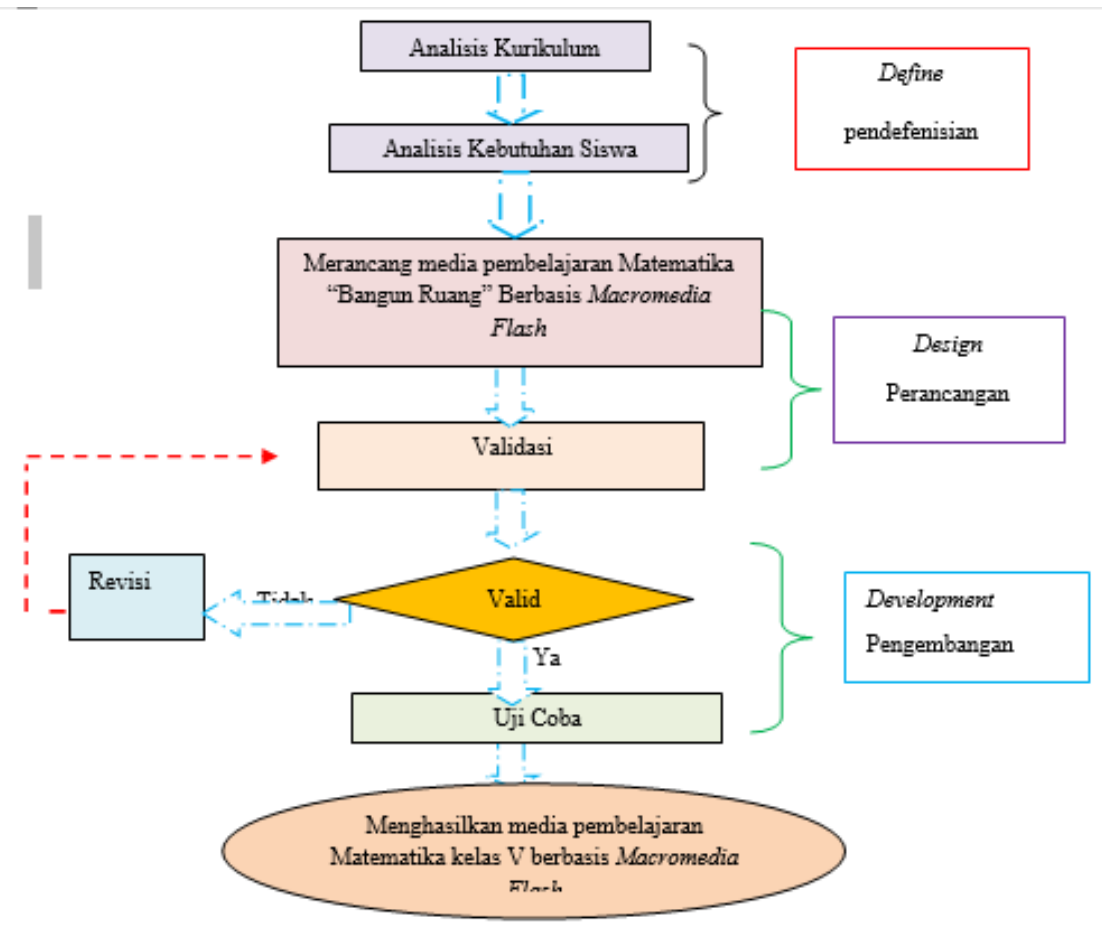

Keterangan:

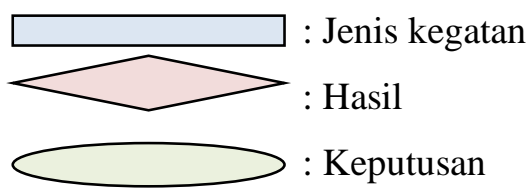

Bagan 1. Prosedur Penelitian

Subjek uji coba pengembangan media pembelajaran Matematika materi Bangun Ruang berbasis Macromedia flash 8 ini dilaksanakan di SD Negeri 55 Aia Pacah pada semester genap tahun ajaran 2019/2020. Subjek uji coba penelitian ini adalah siswa kelas V.b SD Negeri 55 Aia Pacah. Instrumen pengumpulan data berupa lembar tes dan lembar pendapat siswa. Teknik analisis data berupa analisis kevalidan dan analisis kepraktisan. 
Pengembangan Media Pembelajaran Berbasis Macromedia Flash 8 Dengan Pedekatan Contextual Teaching And Learning Pada Materi Bangun Ruang Kelas V SD, Rieke Alyusfitri, Ambiyar, Ishak Azis, Dia Amdia

\section{HASIL}

\section{Tahap Define (Pendefenisian)}

Tahap pendefenisian terdiri dari analisis kurikulum dan analisis kebutuhan. Berdasarkan analisis kurikulum bahwa kurikulum yang digunakan SD Negeri 55 Aia Pacah pada kelas V adalah kurikulum 2013 dengan Kompetensi Dasar (KD) yaitu: 3.5 Menjelaskan, dan menentukan volume bangun ruang dengan menggunakan satuan volume (seperti kubus satuan) serta hubungan pangkat tiga dengan akar pangkat tiga. 4.5 Menyelesaikan masalah yang berkaitan dengan volume bangun ruang dengan menggunakan satuan volume (seperti kubus satuan) melibatkan pangkat tiga dan akar pangkat tiga. Hasil analisis menunjukkan bahwa media pembelajaran yang dibutuhkan adalah media pembelajaran interaktif yang berisi materi dan latihan soal yang dikemas dalam bentuk media pembelajaran macromedia flash dengan pendekatan CTL yang bersifat kemandirian siswa dalam pembelajaran. Model pembelajaran ini diharapkan dapat menimbulkan antusias siswa, prkatis dan lebih bermakna.

\section{Tahap Design (Rancangan)}

Tahap design dilakukan dengan tujuan menghasilkan perancangan media pembelajaran interaktif matematika berbasis macromedia flash mengenai materi bangun ruang. Adapun tahap design sebagai berikut:

\section{Membuat Garis Besar Program Media}

Garis besar program media berisi identifikasi program media interaktif yang akan dibuat.

Melalui identifikasi ini maka dapat ditentukan beberapa hal sebagai berikut:

Tabel 1.

Garis Besar Program Media Pembelajaran Matematika

\begin{tabular}{|c|l|l|}
\hline No & \multicolumn{1}{|c|}{ Aspek } & \multicolumn{1}{c|}{ Uraian } \\
\hline 1 & Satuan pendidikan & SD Negeri 55 Aia Pacah \\
\hline 2 & Kelas & V \\
\hline 3 & Topik & Bangun ruang \\
\hline 4 & Media & Media pembelajaran interaktif macromedia flash 8. \\
\hline 5 & Validator & $\begin{array}{l}\text { 1. Ade Sri Madona, M.Pd } \\
\text { 2. Dra. Niniwati, M.Pd }\end{array}$ \\
\hline
\end{tabular}

\section{Membuat Flowchar}

Flowchart media pembelajaran interaktif bangun ruang berbasis macromedia flash 8 kelas V SD Negeri 55 Aia Pacah ini akan digunakan untuk merancang storyboard. Flowchart adalah alur program yang dibuat dimulai dari membuka (star). Flowchart media pembelajaran bangun ruang berbasis macromedia flash 8 kelas V SD Negeri Aia Pacah sebagai berikut 


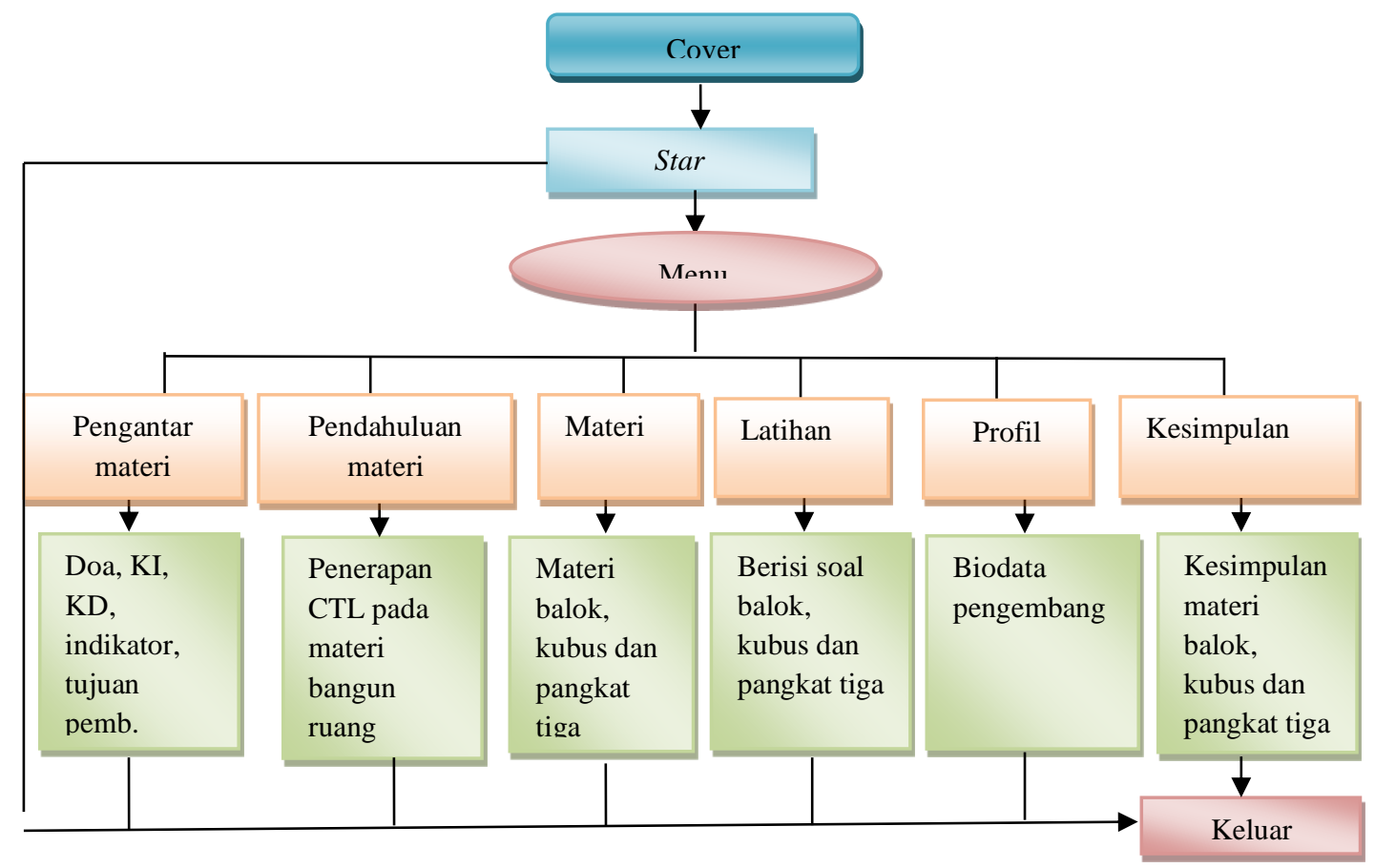

Bagan 2. Flowchart media pembelajaran bangun ruang berbasis macromedia flash 8 kelas V SD Negeri Aia Pacah

\section{Membuat Storyboard}

Storyboardadalah uraian yang berisi tulisan dan gambar dengan penjelasan masing masing alur dalam flowchart mewakili satu tampilan di layar monitor. Storyboard dapat dilihat pada tabel 2.

\section{Tabel 2.}

Storyboard

\begin{tabular}{|c|c|l|l|}
\hline No & \multicolumn{1}{|c|}{ Visual } & \multicolumn{1}{c|}{ Audio } \\
\hline 1 & Bagian & Musik Penggiring \\
\hline & & $\begin{array}{l}\text { Menu cover berisi: } \\
\text {-Judul } \\
\text {-Mata pelajaran } \\
\text {-Materi } \\
\text {-Kelas/semester }\end{array}$ & Musik pengiring \\
\hline 2 & &
\end{tabular}




\begin{tabular}{|c|c|c|c|}
\hline 3 & (ii) & $\begin{array}{l}\text { Menu utama berisi: } \\
\text { - Tombol home } \\
\text { - Tombol petunjuk } \\
\text { penggunaan } \\
\text { - Tombol materi } \\
\text { - Tombol latihan } \\
\text { - Tombol penutup } \\
\text { - Tombol profil } \\
\text { - Tombol cover }\end{array}$ & \\
\hline 4 & 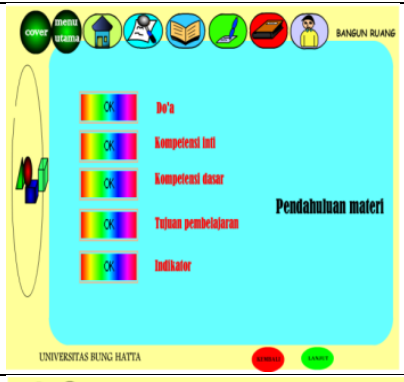 & $\begin{array}{l}\text { Menu home berisi: } \\
\text { Tombol doa } \\
\text { - Tombol kompetensi inti } \\
\text { - Tombol kompetensi dasar } \\
\text { - Tombol tujuan } \\
\text { pembelajaran } \\
\text { - Tombol indikator }\end{array}$ & Musik pengiring \\
\hline 3 & 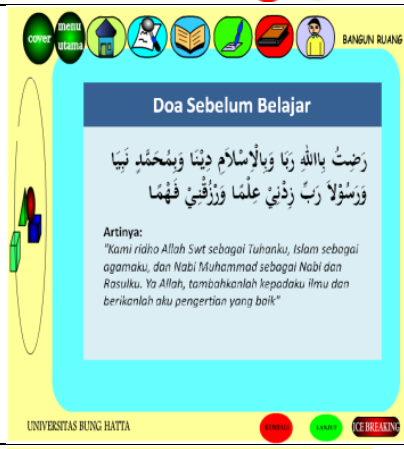 & Menu doa sebelum belajar & \\
\hline 4 & 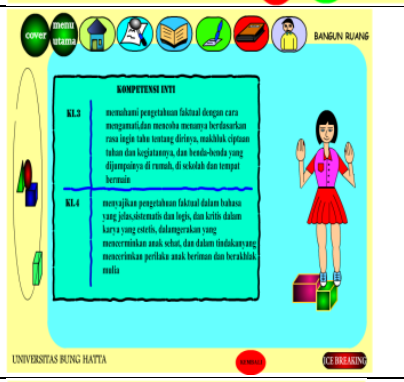 & Menu kompetensi inti & \\
\hline 5 & 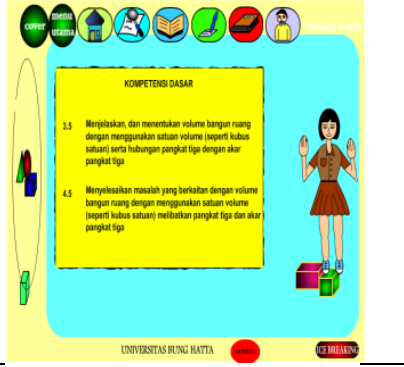 & Menu kompetensi dasar & \\
\hline 6 & 40 (1) & Menu indikator & \\
\hline
\end{tabular}




\begin{tabular}{|c|c|c|c|}
\hline 7 & 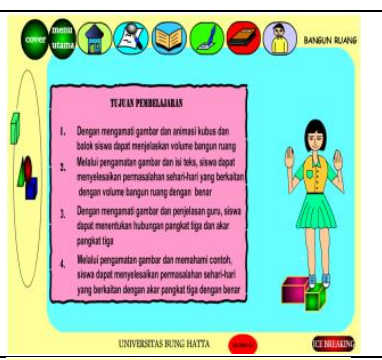 & Menu tujuan pembelajaran & \\
\hline 8 & 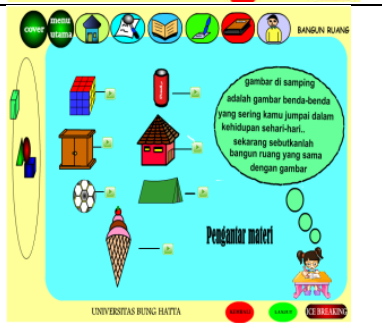 & $\begin{array}{l}\text { Menu ini berisi pengantar } \\
\text { materi bangun ruang }\end{array}$ & Suara materi \\
\hline 9 & 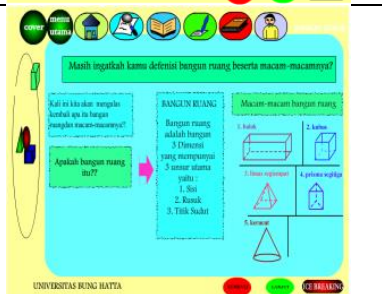 & $\begin{array}{l}\text { Menu ini berisi : } \\
\text { - Defenisi bangun ruang } \\
\text { - Macam-macam bangun } \\
\text { ruang }\end{array}$ & Suara materi \\
\hline 10 & 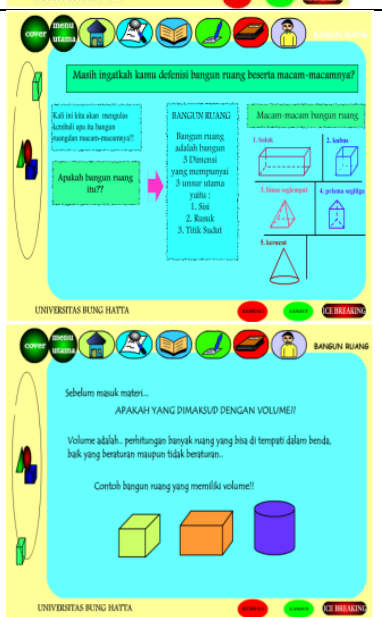 & $\begin{array}{l}\text { Menu ini berisi: } \\
\text { - Pengertian volume } \\
\text { - Bangun yang memiliki } \\
\text { volume }\end{array}$ & Suara materi \\
\hline 11 & Mater Bangun Ruarlo & $\begin{array}{l}\text { Menu materi berisi: } \\
\text { Pilihan materi yang akan } \\
\text { dipelajari }\end{array}$ & \\
\hline 12 & 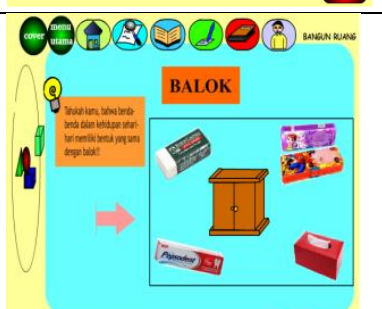 & $\begin{array}{l}\text { Materi balok: } \\
\text { Macam-macam benda yang } \\
\text { memiliki bentuk yang sama } \\
\text { dengan bangun ruang balok }\end{array}$ & Suara materi \\
\hline
\end{tabular}




\begin{tabular}{|c|c|c|c|}
\hline 13 & 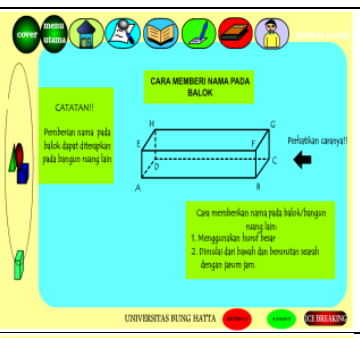 & $\begin{array}{l}\text { Materi cara memberi nama } \\
\text { pada balok dan dapat } \\
\text { diterapkan pada bangun } \\
\text { ruang lain }\end{array}$ & Suara materi \\
\hline 14 & 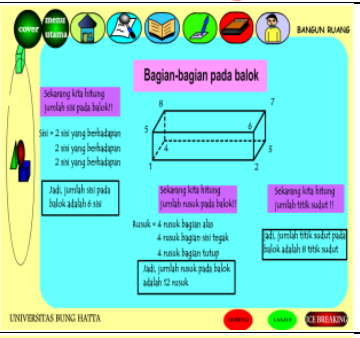 & $\begin{array}{l}\text { Materi yang berisi bagian- } \\
\text { bagian utama pada balok } \\
\text { beserta jumlah } \\
\text { komponennya. }\end{array}$ & Suara materi \\
\hline 15 & ind & $\begin{array}{l}\text { Materi yang berisi cara } \\
\text { menghitung diagonal- } \\
\text { diagonal balok dan jumlah } \\
\text { komponen diagonal. }\end{array}$ & Suara materi \\
\hline 16 & 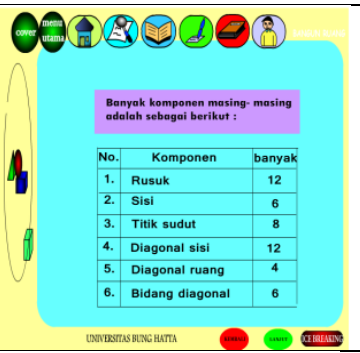 & $\begin{array}{l}\text { Jumlah keseluruhan diagonal } \\
\text { balok. }\end{array}$ & Suara materi \\
\hline 17 & 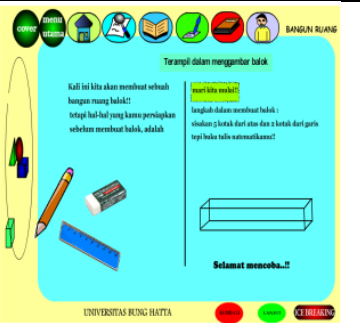 & $\begin{array}{l}\text { Materi yang berisi } \\
\text { bagaimana cara menggambar } \\
\text { balok. }\end{array}$ & Suara materi \\
\hline 18 & 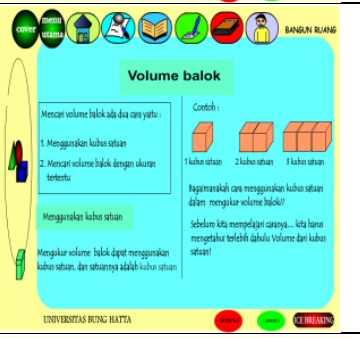 & $\begin{array}{l}\text { Materi yang berisi cara } \\
\text { mencari volume balok } \\
\text { dengan menggunakan kubus } \\
\text { satuan dan mencari dengan } \\
\text { ukuran tertentu }\end{array}$ & \\
\hline 19 & 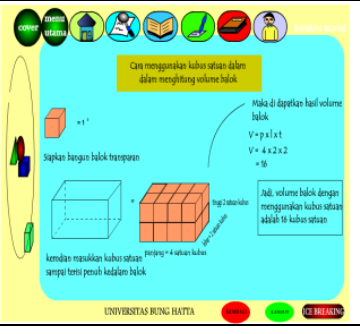 & $\begin{array}{l}\text { Materi yang berisi cara } \\
\text { penggunaan kubus satuan } \\
\text { dalam menghitung volume } \\
\text { balok }\end{array}$ & \\
\hline
\end{tabular}




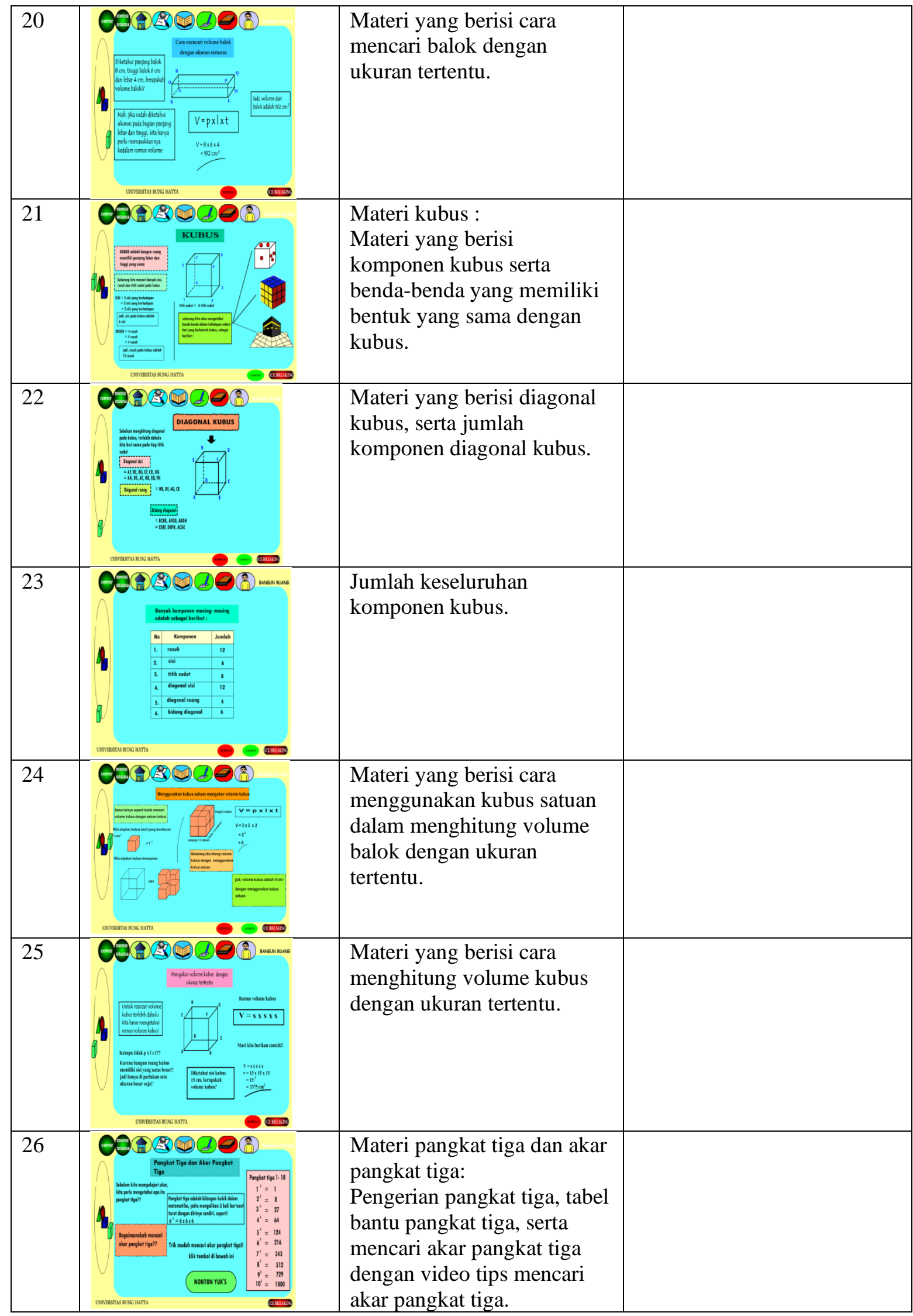


Pengembangan Media Pembelajaran Berbasis Macromedia Flash 8 Dengan Pedekatan Contextual Teaching And Learning Pada Materi Bangun Ruang Kelas V SD, Rieke Alyusfitri, Ambiyar, Ishak Azis, Dia Amdia

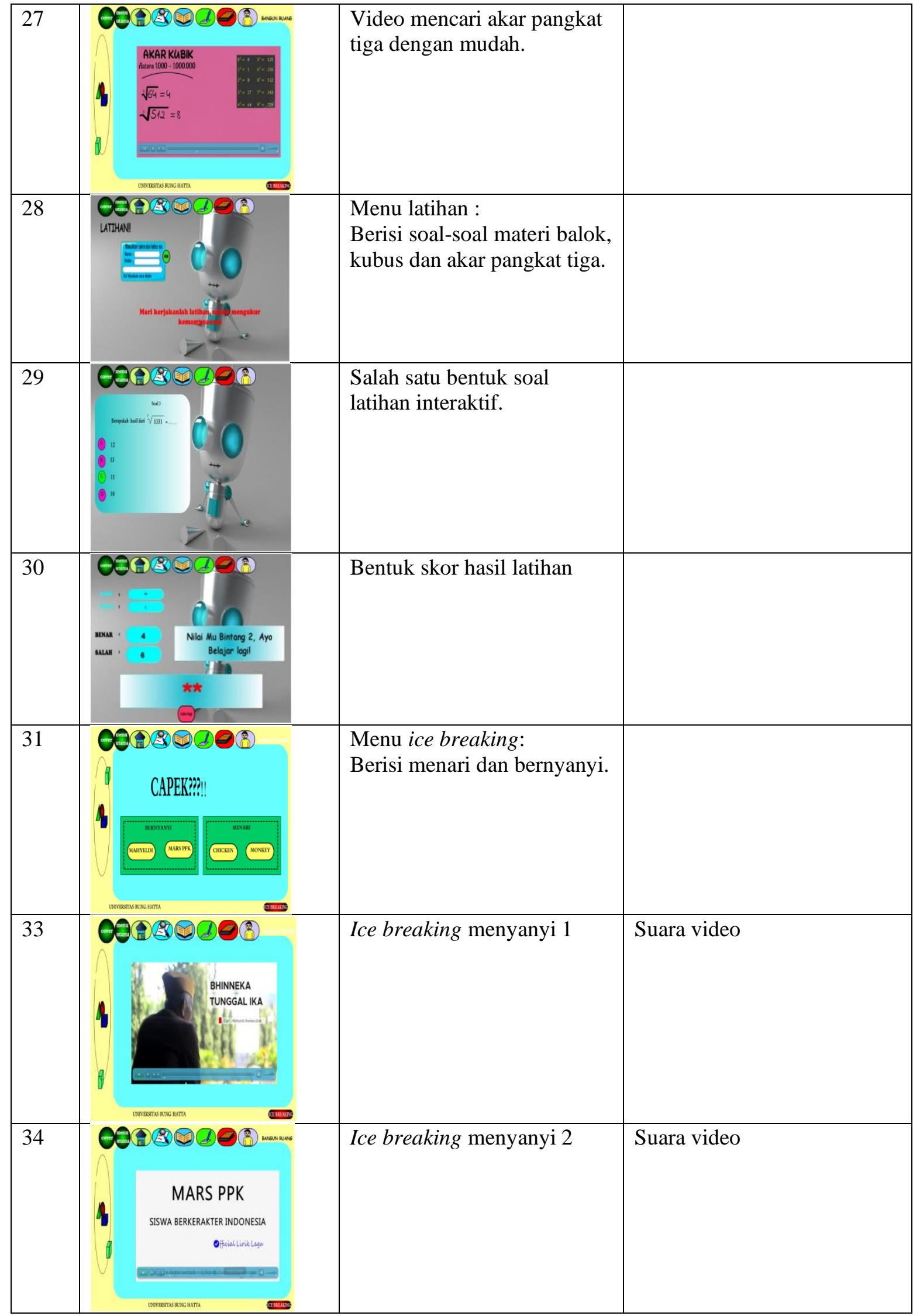




\begin{tabular}{|c|c|c|c|}
\hline 35 & 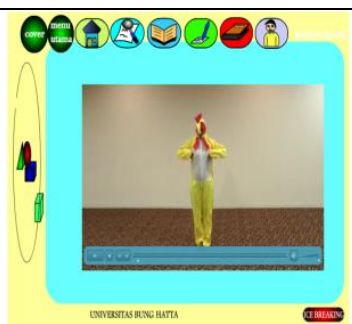 & Ice breaking menari 1 & Suara video \\
\hline 36 & H. & Ice breaking menari 2 . & Suara video \\
\hline 37 & 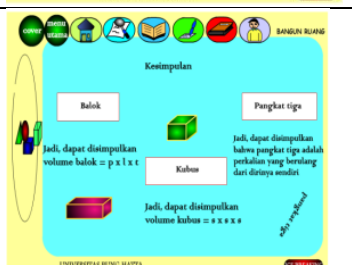 & $\begin{array}{l}\text { Menu penutup berisi : } \\
\text { kesimpulan materi balok, } \\
\text { kubus dan pangkat tiga. }\end{array}$ & Suara materi \\
\hline
\end{tabular}

\section{Pengumpulan Data}

Bahan yang digunakan untuk mengembangkan media pembelajaran matematika berbasis macromedia flash 8 kelas $\mathrm{V}$ adalah materi bangun ruang, rekaman suara, gambar dan musik. Materi bangun ruang kelas $\mathrm{V}$ diperoleh melalui buku guru dan buku siswa. Materi tersebut digunakan sebagai rujukan untuk pembuatan media pembelajaran matermatika berbasis macromedia flash 8 pada materi bangun ruang kelas V SD Negeri 55 Aia Pacah. Gambar yang digunakan sebagai media pembelajaran ini dirancang sendiri oleh peneliti dan sebagian kecil diperoleh dari google serta rekaman suara direkam dari suara peneliti, serta musik diperoleh dari google dan video yang diperoleh dari google.

\section{Pemrograman}

Analisis pemograman media pembelajaran matematika berbasis macromedia flash 8 pada materi bangun ruang kelas V SD menggunakan macromedia flash 8 yang analsis spesifikasi teknis. Secara teknis, media pembelajaran matematika berbasis macromedia flash 8 pada materi bangun ruang kelas V SD dirancang dengan menggunakan macromedia flash 8. perangkat keras yang dibutuhkan untuk menjalankan media pembelajaran matematika berbasis macromedia flash 8 adalah laptop, infokus dan speaker.

\section{Finishing}

Finishing adalah proses penyelesaian akhir media pembelajaran matematika berbasis macromedia flash 8 pada materi bangunruang kelas V SD berupa pengemasan program dalam bentuk file macromedia flash 8 yang siap digunakan. 
Pengembangan Media Pembelajaran Berbasis Macromedia Flash 8 Dengan Pedekatan Contextual Teaching And

\section{Tahap Develop (Pengembangan)}

\section{Analisis Validasi}

\section{Validasi ahli materi}

Media pembelajaran matematika berbasis macromedia flash 8 pada materi bangun pada kelas V SD yang dikembangkan oleh peneliti kemudian divalidasi. Validasi oleh ahli materi dilakukan dengan maksud untuk menyesuaikan materi yang diajarkan di sekolah dengan kurikulum yang berlaku.

\section{Validasi ahli tampilan}

Media pembelajaran matematika berbasis macromedia flash 8 pada materi bangun ruang kelas V SD yang dikembangkan oleh peneliti kemudian divalidasi. Validasi oleh ahli tampilan dilakukan dengan maksud untuk menyesuaikan tampilan sesuai dengan karakteristik materi dan karakteristik siswa SD.

Tabel. 3

Rekapitulasi Hasil Analisis Validasi

\begin{tabular}{|l|l|c|c|c|c|}
\hline No & $\begin{array}{c}\text { Aspek yang } \\
\text { divalidasi }\end{array}$ & $\begin{array}{c}\text { Jumlah Skor } \\
\text { Validator }\end{array}$ & $\begin{array}{c}\text { Skor } \\
\text { max }\end{array}$ & \% & Keterangan \\
\hline 1 & Aspek Materi & 62 & 64 & $96,8 \%$ & Sangat Valid \\
\hline 2 & Aspek Tampilan & 56 & 60 & $93,3 \%$ & Sangat Valid \\
\hline & & & & $96,3 \%$ & Sangat Valid \\
\hline
\end{tabular}

Berdasarkan rekapitulasi analisis hasil validasi menunjukkan bahwa media pembelajaran matematika berbasis macromedia flash 8 pada materi bangun ruang kelas V SD dari ahli materi dan ahli tampilan memenuhi kriteria sangat valid dengan persentase $96,3 \%$ yang berarti media pembelajaran dapat digunakan tanpa revisi sebagai media pembelajaran matematika di sekolah dasar.

\section{Analisis Praktikalitas}

\section{Analisis angket respon guru}

Angket respon guru diisi oleh ibub Asnelly Sjam, S.Pd, setelah proses pembelajaran menggunakan media pembelajaran matematika berbasis macromedia flash 8 pada materi bangun ruang kelas V SD Pada tanggal 14 Maret 2020 di kelas V.b.

\section{Analisis Angket Respon Siswa}

Angket respon siswa diisi oleh 2 siswa kelas V.b karena keterbatasan kondisi. Angket respon siswa diisi setelah proses pembelajaran yang disampaikan oleh guru kelas V.b dengan menggunakan media pembelajaran matematika berbasis macromedia flash 8 pada materi bangunruang kelas V SD pada tanggal 14 Maret.

\section{Tabel 4.}

Rekapitulasi Hasil Praktikalitas

\begin{tabular}{|l|l|c|c|c|c|}
\hline No & Aspek yang divalidasi & Jumlah Skor Validator & Skor max & $\mathbf{\%}$ & Keterangan \\
\hline 1 & Aspek Respo Guru & 58 & 60 & $96,6 \%$ & Sangat Praktis \\
\hline 2 & Aspek Respo Siswa & 55 & 60 & $91,6 \%$ & Sangat Praktis \\
\hline & & Rata-Rata & & $94,1 \%$ & Sangat Praktis \\
\hline
\end{tabular}


Hal ini menunjukkan bahwa media pembelajaran matematika berbasis macromedia flash 8 pada materi bangun ruang kelas V SD memenuhi kriteria sangat valid dengan persentase $96,3 \% \%$ hail ini berarti bahwa media pembelajaran matematika berbasis macromedia flash 8 pada materi bangun kelas V SD yang dikembangkang memenuhi kriteria yaitu dari aspek materi dan tampilan, sehingga dapat digunakan tanpa revisi sebagai media pembelajaran matematika kelas V sekolah dasar.

\section{KESIMPULAN}

Berdasarkan data uji coba media pembelajaran interaktif bangun ruang kelas V SD yaitu materi balok, kubus dan pangkat tiga, dapat diperoleh kesimpulan sebagai berikut :Proses pengembangan media pembelajaran interaktif bangun ruang kelas V SD diawali dari proses menemukan masalah dan potensi, dan tahap selanjutnya perencamaan menemukan solusi dari masalah yang dilakukan dengan proses pengumpulan data kemudian merancang design produk media pembelajaran interaktif yang dirasa mempunyai potensi yang dapat membangkitkan semangat siswa untuk belajar sehingga pembelajaran menjadi bermakna. Setelah selesai merancang produk maka dilakukan validasi oleh 2 dosen yaitu ahli materi dan tampilan. Kemudian dilakukan uji coba produk di SD Negeri 55 Aia Pacah.

Hasil dari validitas dan praktikalitas dapat dilihat dari Kevalidan media pembelajaran interaktif bangun ruang dari ahli materi dinyatakan sangat valid dengan persentase $96,8 \%$ dan validasi media dinyatakan sangat valid dengan persentase $93,3 \%$ dari ahli tampilan. Serta analisis dari kedua dosen ahli dinyatakan sangat valid dengan persentase 96,3\%. Sedangkan praktikalitas media pembelajaran interaktif bangun ruang oleh guru dinyatakan praktis dengan persentase 96,6\%. Serta praktikalitas oleh siswa dinyatakan sangat valid dengan persentase $91,6 \%$. Serta analisis dari guru dan siswa dinyatakan sangat valid dengan persentase $94,1 \%$.

\section{DAFTAR PUSTAKA}

Akhmadan, W. (2017). Pengembangan Bahan Ajar Materi Garis dan Sudut Menggunakan Macromedia Flash dan Moodle Kelas VII Sekolah Menengah Pertama. Jurnal Gantang, 2(1), 27-40. https://doi.org/10.31629/jg.v2i1.62

Azriah. (2018). No Peranan Media Pembelajaran Berbasis Multimedia Interaktif Berbantuamacromedia Flash Sebagai Sumber Belajar Mandiri Untuk Meningkatkan Daya Ingat Dan Minat Belajar Peserta Didik Pada Materi Jarak Dalam Ruang Untuk SMA KELAS XII. Gastrointestinal Endoscopy, $\quad$ 10(1), 279-288. http://dx.doi.org/10.1053/j.gastro.2014.05.023\%0Ahttps://doi.org/10.1016/j.gie.2018.04.013\%0 Ahttp://www.ncbi.nlm.nih.gov/pubmed/29451164\%0Ahttp://www.pubmedcentral.nih.gov/articl erender.fcgi?artid=PMC5838726\%250Ahttp://dx.doi.org/10.1016/j.gie.2013.07.022 
Pengembangan Media Pembelajaran Berbasis Macromedia Flash 8 Dengan Pedekatan Contextual Teaching And

Batul, R. Z. (2018). Pengembangan Media Pembelajaran Pohon Pintar Pada Kompetensi Dasar Menerapkan Promosi Produk Kelas X Bisnis Daring Dan Pemasaran Smk Negeri 2 Blitar. Jurnal Pendidikan Tata Niaga (JPTN), 06(4), 192-197.

Fahmi, S., \& Email, I. (2014). Pengembangan Multimedia Macromedia Flash dengan Pendekatan Kontekstual dan Keefektifannya terhadap Sikap Siswa pada Matematika Developing Multimedia Macromedia Flash with Contextual Approach and Its Effect on Students 'Attitude toward Mathematics. 9, 90-98.

Masykur, R., Nofrizal, N., \& Syazali, M. (2017). Pengembangan Media Pembelajaran Matematika dengan Macromedia Flash. Al-Jabar: Jurnal Pendidikan Matematika, 8(2), 177. https://doi.org/10.24042/ajpm.v8i2.2014

Rahayu, S., \& Hidayati, W. N. (2018). Meningkatkan Hasil Belajar Matematika Melalui Penggunaan Media Bangun Ruang Dan Bangun Datar Pada Siswa Kelas V Sdn Jomin Barat I Kecamatan Kotabaru Kabupaten Karawang. Jurnal Pendidikan Sekolah Dasar, 4(2), 204. https://doi.org/10.30870/jpsd.v4i2.3854

Sakti, I., Puspasari, Y. M., \& Risdianto, E. (2012). Pengaruh model pembalajaran langsung. PENgaruh Model Pembalajaran Langsung (Direct Instruction) Melalui Media Animasi Berbasis Macromedia Flash Terhadap Minat Belajar Dan Pemahaman Konsep Fisika Siswa Di SMA PLus Negeri 7 Kota Bengkulu Indra, X(1), 1-10.

Saputra, V. H., \& Permata, P. (2018). Media Pembelajaran Interaktif Menggunakan Macromedia Flash Pada Materi Bangun Ruang. WACANA AKADEMIKA: Majalah Ilmiah Kependidikan, 2(2), 116. https://doi.org/10.30738/wa.v2i2.3184

Setyono, T., Eka, L., Deswita, H., \& Belakang, A. L. (2017). Pengembangan Media Pembelajaran Matematika Dengan Menggunakan Macromedia Flash Pada Materi Bangun Ruang Kelas VIII Sekolah Menengah Pertama. Jurnal Fakultas Keguruan Dan Ilmu Pendidikan Universitas Pasir Pengaraian, 2(1), 1-10.

Sipayung, A. (2018). Meningkatkan Pemahaman Konsep Matematika tentang Sifat-Sifat Bangun Ruang Sederhana melalui Contextual Teaching and Learning. Mosharafa: Jurnal Pendidikan Matematika, 7(3), 401-412. https://doi.org/10.31980/mosharafa.v7i3.153

Subaidi, A. (2016). Penerapan Pendekatan Contextual Teaching And Learning ( Ctl ) Dengan Setting Model Learning Together ( Lt ) Pada Pokok. Sigma, 2(1), 1-4.

Sulistyowati. (2013). Pengembangan Media Pembelajaran Interaktif Dengan Pendekatan Contextual Teaching and Learning ( Ctl ) Pada Materi Volume Bangun Ruang. November, 978-979. 
Sutopo, H. (2011). Selection sorting Algorithm Visualization Using Flash. The International Journal of Multimedia \& Its Applications, 3(1), 22-35. https://doi.org/10.5121/ijma.2011.3103

Sutriyono, Fitriyana, N., \& Adha, I. (2020). Pengembangan Media Pembelajaran Matematika Macromedia Flash Berbasis Pendekatan Kontekstual. Jurnal Pendidikan Matematika Undiksha, 11(1), 2599-2600.

Syafwan, H., Afriyanti, R., Imam, J., \& No, B. (2017). Perancangan Media Interaktif Untuk Pembelajaran Rantai. 2(April), 39-44.

Trisnawati. (2015). Pembelajaran Kontekstual ( Contextual Teaching and Learning ) Pada Bangun Ruang Sisi Datar di Sekolah Dasar. Jurnal Pendidikan Ke-SD-An, 1(3), 146-155. 